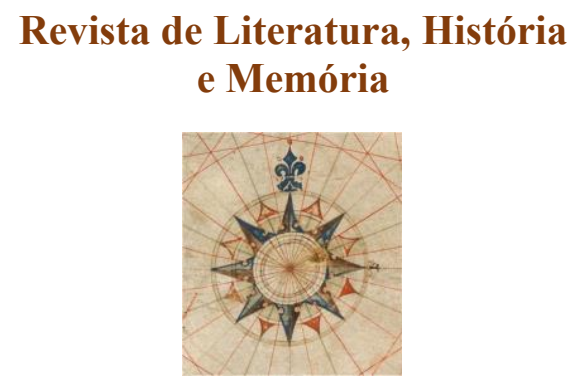

Dossiê: Manifestações de re-existência: a literatura em tempos de repressão

\section{ISSN 1983-1498}

VOL. 16 - No 27 - 2020

U N I O E S T E / CA S C A V E L - p. 176-200

\title{
A LITERATURA GÓTICA DE AUTORIA FEMININA NA INGLATERRA DOS SÉCULOS XVIII E XIX: RESISTÊNCIA À IDEOLOGIA HEGEMÔNICA
}

\author{
The writing of gothic literature by female authors in
} $18^{\text {th }}$-and- $19^{\text {th }}$-century England: a narrative of resistance to hegemonic ideology

\author{
Rosana Ferrari Pandim Lisboa Teixeira ${ }^{1}$ \\ Priscilla Melo Ribeiro de Lima
}

RESUMO: O objetivo central deste artigo é compreender como a escrita de horror gótico por mulheres se configurou enquanto narrativa de resistência à ideologia hegemônica. Primeiramente, traçamos um panorama histórico da Inglaterra dos séculos XVIII e XIX e as proposições ideológicas que a marcaram. Depois, realizamos uma análise do gênero gótico enquanto sintoma da Modernidade capitalista, capaz de capturar suas angústias, fissuras e conteúdos recalcados. A partir disso, pensamos na possibilidade de escrita gótica de autoria feminina que se desenvolveu neste período enquanto um discurso de resistência, de denúncia e crítica social. Esses elementos deram suporte a uma leitura de Frankenstein, de Mary Shelley, epítome do gótico, enquanto obra primordial para a compreensão da resistência feminina ao empunhar a caneta. Para tanto, foram necessários os escritos de Marx, Eagleton e Federici acerca da ideologia e da condição feminina, a concepção de narrativas de resistência de Bosi e a análise da escrita por mulheres de Gilbert e Gubar, sobre um pano de fundo psicanalítico. As escritoras conseguiram, ao ousar uma incursão na escrita, escrever as suas histórias e a de tantas outras mulheres. Shelley, em especial, ao gerar e dar voz a uma criatura que corporifica os dilemas da sociedade e as angústias de grupos marginalizados.

PALAVRAS-CHAVE: Discurso de resistência; Frankenstein; Autoria feminina; Ideologia; Gótico.

ABSTRACT: The main aim of this article is to understand how the writing of gothic horror by women configured as a narrative of resistance to hegemonic ideology. First, we traced a historical outlook of $18^{\text {th }}$-and- $19^{\text {th- }}$ century-England and the ideological propositions that framed it. Afterwards, we analyzed the gothic genre as a symptom of capitalist Modernity, capable of capturing its angsts, clefts and repressed contents. After that, we analyzed gothic female writing developed on that period as a resistance discourse and a form of social critique. Those elements supported our reading of Frankenstein, by Mary Shelley, gothic epitome, as a work of paramount importance to the idea of female resistance by having the pen in their hands. In order to do so, Marx's, Eagleton's and Federici's works on ideology and the female condition were necessary, as well as Bosi's notion of resistance narratives and Gilbert and Gubar's analysis on writing by female authors, over a psychoanalytical background. Female writers, while daring to create, were able to write their stories and those of many other women. Especially Shelley, while generating and giving voice to a creature who embodies society's dilemmas and the angsts of marginalized groups.

KEYWORDS: Resistance discourse; Frankenstein; Female authorship; Ideology; Gothic.

Mas é justamente assim. O anjo decaído torna-se demônio. Entretanto, mesmo aquele inimigo de Deus e do homem tinha amigos e seguidores.

\footnotetext{
${ }^{1}$ Mestranda em Psicologia pela Universidade Federal de Goiás.

${ }^{2}$ Professora Adunta da Faculdade de Educação da Universidade Federal de Goiás FE-UFG). Coordenadora do Programa de Pós-graduação em Psicologia (PPGP-UFG).
} 
Eu estou sozinho.

Mary Shelley

(em Frankenstein ou o Prometeu Moderno, $1831 / 2015$, p. 204).

O contexto histórico-social deste trabalho é a Inglaterra da Modernidade, durante o período vitoriano. Nesse momento de ruptura histórica, desenvolveu-se a escrita gótica - um movimento literário em contraposição aos ideais iluministas de suposto progresso científico. O romance gótico é uma analogia à atualização da arquitetura gótica que se iniciou na metade do século XVIII. Além de uma reação aos ideais iluministas, é, também, uma resposta ao romance tradicional do século XVII, capitaneado pelos autores Daniel Defoe, Samuel Richardson e Henry Fielding. A inovação, segundo Clery (2002), não foi bem vista pelo meio literário em um primeiro momento, mas, posteriormente, o gênero ganhou uma nova força com o desenvolvimento industrial.

O gótico representa a paranoia, a angústia, os tabus, a barbárie e todas as contradições estruturais que uma dada cultura tenta veementemente reprimir ou esconder (MELLOR, 2003). Ele pode ser compreendido como uma rede de metáforas interconectadas, afirmam Wallace e Smith (2009), já que utiliza de símbolos, significados, metáforas e hipérboles para tecer críticas sociais e realizar denúncias. Esses elementos são fundamentais para a psicanálise, corpo teórico que já nasce em relação com a literatura. Tanto o gótico quanto a psicanálise surgem do mesmo desconforto cultural (MASSÉ, 2012), a relação da Modernidade e do início do capitalismo com o mal-estar social e individual dos sujeitos deste tempo.

Massé (2012) indica que, assim como a psicanálise dissolve as barreiras entre indivíduo e sociedade, demonstrando que o ser é social, analisar o gótico leva à mesma conclusão. Ambos desvelam as proposições ideológicas que permitem a propagação do horror e do mal-estar. Assim como o inconsciente, o texto gótico é composto por diversas camadas de significado com múltiplas possibilidades de interpretação, incorporando, textualmente, o estranho freudiano. As metáforas góticas, entretanto, não devem ser analisadas separadamente de seu contexto histórico, já que estão imbuídas pela ideologia hegemônica do momento em que foram geradas. Trazem consigo, portanto, todas as contradições de sua época. Tendo isso em mente, utilizaremos a psicanálise para aprofundar em alguns conceitos que ajudarão a melhor compreender o gótico, como o mal-estar referente a seu contexto histórico e o abjeto da escrita de autoria feminina.

De acordo com Rossi, Zanini, Barros e França (2018), o que é recalcado no 
pensamento iluminista é revelado enquanto monstruosidade de maneira fantasmática: não somente as fendas que correspondem ao inconsciente, mas também os símbolos da época, de forma que a simbologia gótica está tão presente no ideário de fin-de-siécle e do período vitoriano que sua presença tentacular pode ser vista até mesmo no tema fantasmagórico de Marx acerca das mercadorias da sociedade capitalista, ainda que indiretamente. Isso porque, de acordo com Löwy e Sayre (2015), o romantismo (e, portanto, também o gótico, fruto desse movimento) não se restringe a produções culturais, mas deve ser compreendido como uma visão de mundo, uma estrutura mental coletiva. Essa estrutura se exprime nos mais diversos âmbitos da vida social, como na filosofia, na teologia, no pensamento econômico, político e jurídico, por exemplo. Assim, para além de uma caracterização das manifestações culturais literárias e artísticas românticas ou da delimitação do romantismo a um determinado período histórico, a construção de Löwy e Sayre permite a análise do movimento como um atravessamento em múltiplas esferas da vida. O que une suas diversificadas expressões é a “oposição ao mundo burguês moderno" (p. 29).

A repaginação do romance como gênero gótico aparece também como um sintoma do crescimento da indústria editorial e enquanto resposta à procura de novidades e leituras, já que o acesso ao texto se tornou mais fácil e, portanto, ocorreu em maior escala (CLERY, 2002). Assim, até mesmo um gênero literário que surge como proposta subversiva foi, de alguma maneira, cooptado pelo sistema capitalista de então como forma de lucro e vendas. Como afirmam Marx e Engels (1845-1846/2007), o produto que se torna mercadoria é o produto desejado justamente pela classe dominante que, de uma forma ou de outra, será utilizado independentemente do querer dos homens. Assim, ainda que não conseguissem minar completamente a crítica presente na literatura gótica (provavelmente devido à utilização de camadas densas de símbolos e significados), o capital conseguiu utilizá-la para, ainda assim, gerar algum tipo de lucro.

Devido ao seu teor crítico, muitos textos góticos foram considerados uma forma inferior de arte, um entretenimento efêmero e sem grande valor cultural, contribuindo para a tentativa de esvaziamento de seu potencial de crítica para o grande público. A utilização de símbolos e metáforas, ainda que não completamente consciente por todos os autores e autoras do gótico, foi o que fez com que os textos fossem distribuídos e publicados, já que as denúncias sociais não estavam expostas de forma direta. Foi assim, portanto, que mulheres escritoras conseguiram inserir em seus textos suas angústias e realizar críticas à ideologia hegemônica. 


\section{O GÓTICO FEMININO E A IDEOLOGIA}

Wallace e Smith (2009) afirmam que após a criação inicial do termo female gothic, muitas variações da nomeação de textos góticos escritos por mulheres surgiram na crítica literária, fazendo com que o termo seja ao mesmo tempo pioneiro e centro de debates. Os estudiosos comentam a visão de alguns críticos literários que analisam o gótico a partir de um viés psicologizante, dispensando uma percepção histórica da realidade das escritoras dos séculos XVIII e XIX. A discussão não é infundada, já que por vezes pesquisadores se incutem em uma análise selvagem tanto de obras quanto de personagens e autores. O que Wallace e Smith (2009) também pontuam, entretanto, é que existem tendências críticas capazes de unir uma interpretação psicanalítica com uma percepção histórica que não faça vista grossa ao contexto material e ideológico, que está irreversivelmente costurado no texto de qualquer autor, em qualquer época.

O termo female gothic é importante, ainda que passível de críticas, porque marca um momento na crítica literária no qual colocou-se em voga as conexões latentes entre as mulheres e não somente o gótico, mas também todo o campo da escrita do horror, reconhecendo que poderia haver alguma forte relação entre as metáforas do horror e a questão de gênero. Este momento foi imprescindível, de acordo com Fitzgerald (2009), para salvar a reputação de autoras do horror que eram consideradas, até então, infantis ou desprovidas de valor literário real. A crítica literária de viés feminista foi, assim, uma das grandes responsáveis por institucionalizar o gênero gótico como um braço da literatura digno de ser estudado.

O mais recente movimento no campo de análise literária do gótico é a leitura voltada para a percepção histórica e materialista dos elementos do gênero, como o trabalho de Clery (2000), mencionado por Wallace e Smith (2004). Nesse estudo, Clery contextualiza os textos góticos de autoria feminina de acordo com a vida material de escritoras no período Romântico europeu. Clery (2000) destacou suas inoperantes condições de isolamento e opressão juntamente à autocrítica e autocensura, que emulam a crítica e a censura advindas da sociedade. Entretanto, ela aponta que, apesar do contexto desfavorável, existiam mulheres com status social e econômico atuando como escritoras profissionais, inspiradas por Sarah Siddons, importante figura feminina e ideal de intelectualidade. Nesse sentido, percebemos que as condições materiais nas quais as autoras estavam inseridas são imprescindíveis para uma análise aprofundada de seus textos. A ideologia hegemônica e o período histórico criticados pelo gótico e nos quais ele está inserido são os mesmos em relação aos quais Marx 
e Engels tecem suas formulações. A escrita de "A Ideologia Alemã", por Marx e Engels (1845-1846/2007), diz respeito a uma crítica satírica à filosofia idealista alemã e a todo o modo de produção, desde a realidade industrial inglesa, que fez com que emergisse o debate acerca da classe trabalhadora, suas insalubres condições de trabalho no século XIX e as contradições da sociedade burguesa.

Assim, quando Marx e Engels (1845-1846/2007) revelam que, com o desenvolvimento do capitalismo a sociedade se encontra subjugada ao lucro, à mercadoria, ao capital e à divisão social do trabalho, enfim, às próprias relações da materialidade, podemos pensar que há uma divisão social na qual a mulher, de acordo com Silvia Federici (2004/2017), é marcada por um contexto de exploração. Segundo a autora, que se utiliza dos textos marxistas, desde o contexto da Baixa Idade Média até o surgimento dos Estados Absolutistas, houve uma regulação dos papeis sociais que homens e mulheres deveriam realizar, o que fez com que a mulher ficasse presa a uma posição inferiorizada devido a leis e normas como, por exemplo, a lei da legalização do estupro. Para além da óbvia subjugação da mulher, inclusive no campo sexual, assim como a formalização de sua caracterização como objeto, um dos processos resultantes dessa diferenciação social homem/mulher foi, por exemplo, a caça às bruxas. Não é, portanto, coincidência que a presença de bruxas e do oculto seja frequente e parte constituinte do arcabouço simbólico do movimento literário gótico.

Com a estabilização dos Estados Absolutistas, emergiu o conceito de "feminilidade" concomitantemente às ressignificações de funções e normas sociais que acabaram por segregar ainda mais insistentemente os papeis de homens e mulheres na sociedade. Federici (2004/2017) evidencia que o auge das reformulações das relações de trabalho foi a criação, no século XIX, da função de "dona de casa de tempo integral", que distanciou ainda mais a mulher da vida pública e fortaleceu a percepção de sua incumbência máxima como reprodutora biológica. Denominado por Virginia Woolf (1942/2012) como o "anjo do lar", essa função ideológica é responsável por grande parte das contradições femininas do período, refletindo diretamente nas metáforas góticas a serem discutidas neste trabalho. Federici (2004/2017) estabelece como sua tese central que a caça às bruxas foi um processo planejado e desenvolvido pela junção entre Estado e Igreja com o intuito de disciplinamento social e corporal. Esse fenômeno histórico culminou no surgimento do modelo de feminilidade a partir da destituição da mulher da esfera pública e dos sistemas do conhecimento. O cânone cultural percebia a mulher, portanto, como insubordinada, rebelde e intelectualmente débil, o que fez com que fosse necessária sua domesticação e docilização. Não podemos deixar de ter em mente que essas perseguições somente ocorreram como forma de dominação porque as 
mulheres tentaram ativamente resistir às relações capitalistas.

Outro ponto de convergência entre literatura gótica de autoria feminina e dos escritos de Federici (2004/2017) é o interesse implícito e ideológico da burguesia de desclassificar pensamentos que destoassem dos ideais iluministas de cientificismo, positivismo e racionalidade. Nesse sentido, o principal ataque foi ao pensamento mágico ou sobrenatural, que, destituído pela burguesia, facilitou a aceitação da ideia de que, de acordo com evidências científicas, o mundo "é como é" - pensamento que perdura até os dias de hoje e um dos responsáveis pelo fatalismo que impede ações, de fato, revolucionárias. A dicotomia iluminista de razão/paixão e mente/corpo se desdobrou também em homem/mulher, inserindo o corpo, as paixões e as mulheres em uma lógica de culpabilização por serem as fontes dos males e impedimento de progresso. O gótico, assim como todo o movimento Romântico, foi absolutamente contra essa lógica simplista, e se preocupou com as consequências para a humanidade tanto em relação a dicotomias como em relação ao controle das naturezas humanas, o que, por fim, se tornou o controle da classe dominante sobre o mundo natural.

De acordo com Marx e Engels (1845-1846/2007), a análise da estruturação da sociedade civil burguesa permite a compreensão de que as formas de viver, ser e agir no mundo são determinadas pelas relações econômicas e sociais de produção e reprodução da vida. São justamente essas relações que compõem a estrutura material da sociedade responsáveis pelas crenças que Terry Eagleton (1997) chama de ideologia. Nesse sentido, Marx e Engels (1845-1846/2007) definem ideologia como um sistema de pensamento e de poder que versa sobre a forma de concepção de mundo, e, em especial, do mundo social e material. As noções predominantes de cada época interessam à preservação dos interesses da classe dominante, de forma a manter as relações de produção e reprodução social. Em relação a isso, Eagleton (1997) pontua que não necessariamente a ideologia partirá da classe dominante em si, mas da estrutura material e social como um todo, de forma a manter, direta ou indiretamente, consciente ou inconscientemente, um modelo dominante.

Pensar que ideologia é uma "falsa consciência" ou é constituída de "falsas crenças" não é uma possibilidade, já que, como ela é desenvolvida por toda a estrutura social, ela advém de relações vivenciadas e da própria materialidade. Isso porque, como anuncia Eagleton (1997), não faz sentido pensar que um número tão gigantesco de sujeitos viveria e morreria por ideias que são completamente irreais, errôneas ou irracionais, já que isso implicaria dizer que grande parcela dos seres humanos é incapaz de realizar pensamentos racionais e "dissipar" essas crenças ideológicas de sua visão. A forma de funcionamento e ação da ideologia não é assim tão simplista. Supõe-se, então, que, devido a seu caráter 
duradouro e disseminado, essas ideias codificam e partem de desejos e necessidades genuínos. Apesar de termos noção do quão inadequado é generalizar desigualdades ou características de classes ou raças inteiras de pessoas - justamente como o que é feito com as mulheres -, podemos compreender a lógica que levou a essa ação. Na questão feminina especificamente, viu-se, com Federici (2004/2017), como um longo processo histórico levou tanto à caça às bruxas como à inferiorização da mulher. Caso tivesse sido baseado meramente em "crenças falsas" e errôneas, o processo nunca teria sobrevivido até o século XIX e muito menos até as suas novas roupagens contemporâneas.

Para que a ideologia, então, seja eficaz na sociedade, ela deve trazer algum tipo de sentido à experiência das pessoas, ou seja, partir de um local conhecido da realidade social e da interação com essa - dos modos de produção e reprodução da vida. Eagleton (1997) afirma que a ideologia deve ser pensada para além de uma "ilusão" criada e imposta por um grupo, mas como comunicação de uma versão da realidade social compreendida por ele como real o suficiente para não ser rejeitada imediatamente. Compreender que algo da ideologia parte de esferas da realidade não significa dizer que as proposições ideológicas de inferioridade e irracionalidade das mulheres sejam reais ou não-preconceituosas. Assim, classificar esses enunciados enquanto ideológicos é entendê-los como carregados de um motivo ulterior que se relaciona com a legitimação de interesses de grupos em uma luta de poder. Existem razões vinculadas às relações com a ordem social dominante que fazem com que seja necessário e desejoso inferiorizar e deslegitimar certos grupos sociais.

O que pensamos se forma nas relações sociais, constrangidas por uma cultura e sociedade específicas. Assim, é necessário questionar o caráter absoluto e inquestionável usualmente atribuído à ideologia, que se torna independente das relações sociais que as teceram, convertendo-se num produto em si. Nesse sentido, apesar da ideia de inferioridade feminina aparecer enquanto um produto, fixo e alheio ao modo de produção da vida, foi e é recriada dia após dia nas relações sociais. As proposições ideológicas que partiram da realidade e da perspectiva de um grupo que historicamente se fez superior, como viu-se com Federici (2004/2017), trazem algo do real de determinada camada social, e se torna uma proposição ampla a partir da reprodução da vida, das relações sociais e do conflito de classes.

Desse modo, o discurso ideológico traz em si dois componentes: um empírico - algo do real que se mostra como verdadeiro devido à sua materialidade e reprodutibilidade; e um normativo - que orienta os comportamentos e as ideias em determinada direção, apassivando alguns e dando poder a outros. Pensar o componente normativo é observar redes simbólicas pelas quais as proposições ideológicas podem ser difundidas e assentadas como definitivas, 
como a ciência, a arte, a mídia e, no caso deste trabalho, a literatura e a cultura. Isso pois, de acordo com Bosi (2002), as tensões do mundo e da materialidade também se mostram na literatura. Alguns grupos, que detêm acesso privilegiado, controle do meio literário e instrumentos simbólicos, disseminam seus valores e ideologia através de representações discursivas, entre elas, o romance de ficção. De acordo com Lima, Lima e Coroa (2016), esse poder legitimador se torna abusivo quando utiliza os referidos veículos para manter seu legado e prosseguir com o controle e dominação de grupos marginalizados. Os discursos imbricados nos textos literários detêm em si a possibilidade de transformar a realidade, como narrativas de resistência, ou simplesmente sustentar o status quo.

Para Bosi (2002), alguns autores e autoras conseguem expressar algo que vai além do dia a dia mecânico, da mera imitação da existência, em textos denominados por ele como "escritas de resistência". Tais escritas são atravessadas pela tensão de forma crítica e conseguem demonstrar que o que é considerado "vida como ela é" (p. 23) diz respeito a uma vida alienante e alienada. Se dentro da literatura os grupos hegemônicos conseguem se valer das práticas discursivas para reiterar sua posição de poder e dominação, a partir da contradição dialética inerente à materialidade podemos pensar que também é possível desenvolver resistência nesse espaço. Ao desenvolver escritas que contestem, denunciem ou subvertam a ordem, alguns escritores possibilitam a compreensão da ideia de Eagleton (1997) de que os indivíduos são levados a crer nas proposições ideológicas como verdades absolutas e imutáveis, imunes à contestação. Ao expor esses mecanismos de poder e controle, diretamente ou indiretamente, as narrativas se aproximam das possibilidades de resistência.

Bosi (2002) defende que:

A resistência é um movimento interno ao foco narrativo, uma luz que ilumina o nó inextricável que ata o sujeito ao seu contexto existencial e histórico. Momento negativo em que o sujeito, em vez de reproduzir mecanicamente o esquema das interações onde se insere, dá um salto para a posição de distância, e, deste ângulo, se vê a si mesmo e reconhece e põe em crise os laços apertados que o prendem à teia das instituições (p. 26-27).

Em outras palavras, uma narrativa de resistência consegue expor a conexão dos sujeitos com seu contexto e desvelar o caráter imutável das proposições ideológicas, atrelando-as a um momento específico no tempo e no espaço. Os autores, ao se colocarem em uma nova posição de narrar, reconhecem a si mesmos e a suas realidades, alcançando um nível de crítica e denúncia social capaz de balançar o caráter inalterável da ideologia hegemônica ao mesmo tempo em que dão voz a grupos oprimidos. É necessário pensar tais 
discursos como possibilidades de fragilizar o poder das "elites simbólicas", dentro de suas limitações.

Assim, não podemos compreender a literatura, e os discursos que a perpassam, como isoladas da materialidade, mas enquanto forma de agir e interagir com o mundo e com os demais. Isso significa que o discurso das narrativas é parte de uma relação dialética com as estruturas sociais, construindo e sendo construído por elas, conforme discutido por Lima, Lima e Coroa (2016): “constituídos como práticas, os discursos tanto seguem no sentido de reproduzir as relações sociais, como também de transformá-las” (p. 904-905).

Essa construção se aproxima das forças que operam no conceito de campo, em especial no de campo literário, desenvolvido por Bourdieu (1996). Ele supõe a existência de campos enquanto locais de lutas entre forças que almejam conservar as relações de poder estabelecidas ou transformá-las. Quem atua nesses campos são os agentes que podem variar entre sujeitos, instituições e grupos, por exemplo (BOURDIEU, 2004). Tais agentes estão inseridos em estruturas sociais que encerram relações de poder, desenvolvendo-as em suas atuações dentro dos campos nos quais estão inseridos. O campo literário em específico “constitui-se como tal na e pela oposição ao mundo 'burguês' que jamais afirmara de maneira tão brutal seus valores e sua pretensão de controlar os instrumentos de legitimação, tanto no domínio da arte como no domínio da literatura" (BOURDIEU, 1996, p. 75).

No caso da autoria feminina, como já exposto, o controle esteve nas mãos da ampla gama de escritores masculinos e, em sua maioria, burgueses, em especial os que tiveram sua carreira alavancada pelo desenvolvimento da indústria dos livros (como Lamb, Browne, Thackeray, Sterne e Dickens). Ao nos questionarmos acerca das razões da disparidade ou da falta de registros históricos sobre a atuação das mulheres na escrita, Woolf (1929/2019) argumenta que a dificuldade de obter tais dados se dá por eles, em sua maioria, não terem sido compilados. Ela defende que, para descobrir mais sobre a incursão feminina na escrita, devemos nos pautar pela materialidade da vida das mulheres, um pensamento que vai ao encontro do exposto por Federici. Para Woolf, a chave da compreensão dos aspectos que envolvem as vidas das mulheres que se destacaram na escrita e produziram textos subversivos estaria na análise das condições materiais da 'mulher comum': suas condições de vida, especificações de raça e classe, quantidade de filhos, possibilidade de gerir sua vida financeira, acesso ao mercado de trabalho, se tinha ou não empregados, se era ou não uma empregada, se era responsável por trabalho doméstico.

A tese de Woolf (1929/2019) se aprofunda ao perceber que, nos registros acerca da autoria feminina, parecem existir grandes períodos de silêncio. Englobando desde as 
escritoras de poesia nas ilhas gregas à escrita de uma famosa dama da corte japonesa, Woolf demonstra como, entre um pico de desenvolvimento literário e outro, a presença feminina na literatura parece desaparecer. Sua hipótese é a de que o ambiente e a ideologia hegemônica dos períodos históricos são responsáveis por permitir mais ou menos tempo, acesso e liberdade às mulheres. Essa perspectiva é importante tanto para que não se dissemine a ideia errônea de que as mulheres só iniciaram a escrita e a leitura nos séculos XVIII e XIX como para o entendimento de que a reação das mulheres às proposições ideológicas de suas épocas foram tentativas de expressão ao longo das eras.

Nesse sentido, Woolf (1929/2019) também discorre sobre o romance, enquanto gênero literário, como um campo de embate ideológico e possível de construção de narrativas de resistência. Para a escritora, o romance era a forma mais "fácil" de escrita para as mulheres, principalmente no que se refere ao formato. Pausar e retomar a escrita de uma peça ou de uma poesia parece ser um trabalho mais complexo do que com romances, principalmente se fossem divididos em diversos capítulos para publicação em jornais e folhetins. As vidas domésticas das mulheres incluem interrupções constantes por afazeres, tarefas ou chamados. Woolf exemplifica este argumento com relatos das vidas de autoras célebres, como George Eliot, que constantemente pausava sua escrita para cuidar de seu pai, ou Charlotte Brontë, que dividia seu tempo entre a escrita e a cozinha. Assim, devido aos impedimentos da vida material e cotidiana somados às proposições ideológicas hegemônicas propagadas por representações discursivas, o pensamento de Woolf se alinha ao de Federici ao conceberem a importância da carga doméstica que não é imputada ao homem escritor. Nesse sentido, é necessário pontuar que a experiência a qual Woolf se refere diz respeito a mulheres burguesas ou trabalhadoras. As mulheres negras ou de classes sociais menos privilegiadas possuíam ainda mais obstáculos para sua inserção na escrita, além de já estarem trabalhando em diversas posições, como empregadas domésticas ou na prostituição, por exemplo.

À medida em que, dentro dos textos literários, determinados sujeitos ou grupos, neste caso, as mulheres, são representados de forma grotesca, inferior, estranha, ou simplesmente suprimidos das histórias, encontramos um tipo de abuso de poder destinado à manutenção e controle das categorias sociais já existentes. As narrativas veiculadas pelas elites simbólicas são responsáveis pela criação dos denominados “consensos ideológicos identitários" (LIMA; LIMA; COROA; 2016, p. 907), formas de reiterar suas proposições ideológicas enquanto subalternizam as identidades de outros grupos.

Os discursos de resistência visam à criação de formas de relações sociais distintas daquelas do padrão hegemônico. Nelas, os sujeitos encontram espaço para denunciar formas 
de opressão e construir, para si, maneiras de afirmar e transformar suas existências. As narrativas de resistências podem catalisar rupturas na materialidade ou, de acordo com Lima, Lima e Coroa (2016), fraturar a realidade de modo a impactar os sujeitos, alterando suas existências.

A partir das noções de narrativas e discursos de resistência, é possível pensar que as práticas discursivas de escritoras sobre suas realidades, diretamente ou indiretamente, são espaços de construção de novas formas de existir. No papel, conseguem traçar para si um lugar na realidade que lhes fora negado, desestabilizando a hegemonia, criando fissuras nas proposições ideológicas e nos mecanismos de controle e demonstrando que a materialidade pode ser transformada. As autoras conseguem questionar a ideia de que por natureza são inferiores e incapazes, desmerecedoras de educação e vazias de conteúdo digno de ser compartilhado.

Isso não quer dizer que todos os escritos de mulheres serão discursos de resistência, nem que o ato de escrever o seja. De acordo com Gilbert \& Gubar (2000), muitas mulheres corroboraram a ideologia dominante ao perpetuarem textos de manutenção do status quo, como manuais de etiqueta doméstica e tratados sobre a feminilidade. Entretanto, pensando na contradição inerente da materialidade, os sujeitos podem reproduzir ideologias ou usar suas condições discursivas para resistir.

De forma semelhante à compreensão de ideologia de Eagleton (1997), Beauvoir (1949/2010) ressalta que "o mito da mulher desempenha um papel considerável na Literatura" (p. 299), e questiona a importância do mito da mulher na vida cotidiana e em que medida afeta os costumes e as condutas individuais. Para responder a essas perguntas seria necessário "determinar as relações que mantém com a realidade" (p. 343), lançando o olhar, como afirmam Marx e Engels (1845-1846/2007), à realidade social e à produção e reprodução da vida para compreender as proposições ideológicas aqui tratadas. Nesse sentido, observaremos o campo da literatura de autoria feminina para compreender como as autoras dos séculos XVIII e XIX conseguiram, a partir do gótico, subverter e questionar a ideologia hegemônica.

\section{CAMPO LITERÁRIO E ESCRITA DE AUTORIA FEMININA}

A possibilidade de adentrar ao campo literário em busca dessas proposições ideológicas na questão da autoria feminina se dá devido à viabilidade da literatura de exibir a percepção do modo de vida das pessoas, e, portanto, do modo de produção e reprodução da vida. De acordo com Teixeira (2009), o discurso literário comporta uma preocupação com a 
verossimilhança ainda que no campo ficcional. A ficção não é o avesso do real, ou seu negativo, mas uma diferente forma de captá-lo na qual os limites entre criação e fantasia são mais obtusos do que os permitidos por práticas como a historiografia, o que possibilita uma atuação na realidade por vias sinuosas.

Se a realidade feminina é muito representada na literatura de horror e, em especial, gótica de autoria feminina, é porque esse gênero literário ficcionaliza a experiência de horror experienciada pelas mulheres na realidade. Aqui, podemos retomar o conceito de campo literário de Bourdieu (1996), em que a realidade apareceria nas ficções de maneira duplicada. O que se duplicaria, entretanto, seria a chamada ilusão de realidade que é desenvolvida a partir das relações sociais. É em uma outra camada mais profunda que o real se encontra, e é ele que a ficção expõe. Assim, ela funciona de forma semelhante à própria materialidade, dissimulando o real por trás de uma ilusão da realidade. Nesse sentido, o gótico apresenta o mundo sinistro, opressor e violento vivenciado por mulheres e outros grupos marginalizados tanto em sua atmosfera insólita quanto pelos acontecimentos macabros que descreve, ainda que sob diversas camadas de significação.

Anjos (1998), ao comentar Bourdieu (1996), afirma que a literatura, em especial a ficção, é capaz de condensar a complexidade social. E ela consegue fazê-lo por se intitular ficcional, propondo sua existência enquanto desvinculada da realidade. Ao se construir assim, consegue expor a estrutura social, suas contradições e denúncias exatamente por sugestionar que não o faz. A obra gótica, portanto, se insere na concepção de Bourdieu ao denunciar a opressão, a natureza dos discursos ideológicos, as relações de poder e, também, os elementos de resistência, ao propor um universo "fictício". Se a obra ficcional é concebida e produzida em determinado contexto social e cultural, ela atende às necessidades de representação do mundo articuladas aos símbolos da prática social, referentes aos modos de produção e reprodução e à ideologia que advém deles.

Gerard Manley Hopkins, em uma carta para seu amigo R. W. Dixon, em 1886 (apud GILBERT; GUBAR, 2000), afirmou que a qualidade mais essencial do trabalho artístico é sua execução, e que ela se configura como uma possibilidade intrinsecamente masculina, um dos elementos que os separam das mulheres. A partir de relatos e ideias como essa, Gilbert e Gubar (2000) desenvolveram a tese de que a caneta masculina, instrumento utilizado para a escrita, é, em algum sentido, representante do falo, em uma brincadeira irônica com as palavras "pen" e "penis" ("the pen is", "a caneta é" em português e que em inglês remete ao órgão sexual masculino). Essa ideia de soberania masculina, entretanto, não é exclusiva de Hopkins, mas uma expressão da noção ideológica da sociedade de que o escritor age como 
"pai" do texto de forma análoga à maneira que Deus seria o "pai" criador do universo. Esse pensamento perpassa a civilização ocidental e é metaforizado na palavra "autor", descendente de "autoridade". Said (1985 apud GILBERT; GUBAR, 2000) afirma que a palavra autoridade traz uma constelação de significados conectados para além do sentido usual de obediência, poder e influência de ações, mas, também, do próprio autor que cria ou dá a existência a algo - um pai. No reino que o autor cria para si em sua escrita, ele governa como rei absoluto.

Segundo Gilbert \& Gubar (2000), o texto literário consegue dar corpo e formato ao discurso dominante, mas, também, se configurar enquanto uma manifestação física do poder que perpassa essa ideologia. Assim, não só a caneta do escritor escreve e dá corpo à ideologia de sua época, criando um registro e, dessa forma, inscrevendo a própria realidade, como também adquire o poder de criar uma posterioridade. Percebemos que essas narrativas escritas por grupos dominantes reescrevem a história e apagam conflitos e contradições de uma época e de grupos silenciados e sem escrita. Destacamos um deles para o objetivo deste trabalho: as mulheres escritoras.

Muitas delas nem ao menos tentaram usar a caneta, tendo sido impedidas pela noção de que apenas homens teriam o dom da escrita. Outras, "presunçosas e ousadas", cruzaram um território definido "por natureza", já que ler, escrever e até mesmo pensar são atividades que as mulheres, segundo a ideologia dominante, não conseguem realizar devido à sua constituição biológica. Jane Austen, em sua obra "Persuasão", escreve que os "homens têm tido todo tipo de vantagem em relação às mulheres no que diz respeito a contar a sua história. A educação foi dedicada a eles em um nível muito maior; a caneta esteve nas mãos deles [the pen has been in their hands] $]^{3 "}$ (AUSTEN, 1818/2004, p. 281).

Destacamos, então, alguns elementos de análise presentes na literatura escrita por mulheres que nos permitam compreender mais profundamente suas trajetórias no mundo literário e as maneiras pelas quais foram perpassadas pela ideologia hegemônica. Primeiramente, o binômio anjo/monstro construído pelos textos de autoria masculina ao longo da história e o duplo feminino. Depois, a solidão da mulher escritora, os choques iniciais das pioneiras com a sociedade da época. Por fim, o uso de metáforas e camadas de significados nas tramas que permitiram as denúncias e críticas sociais.

Não somente as mulheres foram historicamente impedidas de escreverem suas histórias, como também se tornaram objetos das histórias de autores masculinos, servindo a seus desígnios e expectativas e aprisionadas como personagens em seus textos (GILBERT;

\footnotetext{
${ }^{3}$ Tradução nossa de: "Men have had every advantage of us in telling their own story. Education has been theirs in so much higher a degree; the pen has been in their hands."
} 
GUBAR, 2000). Para adquirirem autonomia literária, as autoras tiveram que, primeiramente, transcender as rasas representações literárias das personagens mulheres de autoria masculina. De certa forma, essas figuras femininas na literatura e na cultura podem ser resumidas ao binômio "anjo" e "monstro", extremos utilizados para diferenciar personagens femininas que correspondiam às expectativas de feminilidade e as que fugiam a tais ideais, seres irracionais e incontroláveis, selvagens. Ortner (1974 apud GILBERT; GUBAR, 2000), no campo da antropologia, estuda como a associação psíquica em relação à mulher se apresentava nos dois extremos de um espectro. Essa ambiguidade simbólica utilizava, em um lado do espectro, símbolos subversivos como a bruxa, o olho maligno, mães castradoras e fálicas, e, do outro, símbolos de poder transcendental feminino, como a representação de justiça, a mãe natureza e mães salvadoras. Assim, a mulher se tornou a corporificação não somente dos extremos simbólicos da humanidade como foi envolvida por uma aura de mistério que a fixava enquanto "outro", seja fonte de medo e repulsa ou de adoração e amor.

O binômio anjo/monstro que cerceou a personagem feminina literária, e, também, a mulher e sua presença na cultura, surgiu na Idade Média. O ideal bíblico de Virgem Maria norteia o ideário feminino até a contemporaneidade, tanto de forma literal com a valorização da virgindade quanto por seu repositório infinito de salvação a ser cultivado pela mulher. A versão da madona pertinente à cultura do século XIX saiu das nuvens dos céus para as casas da época, em formato de "anjo do lar". Com o desenvolvimento do comércio de livros no período, as mulheres que conseguiam ler podiam se educar com obras de etiqueta e conduta que ensinavam submissão, modéstia e doação ao outro, reforçando didaticamente o papel angélico a ser ocupado por elas.

A imagem de anjo carrega em si seu próprio antagonista, a morte. Welsh (1999 apud GILBERT; GUBAR, 2000), em estudos de tais manuais de moralidade e da iconografia angélica vitoriana, afirma que o anjo do lar se aliena de forma tão intensa da vida secular ao seguir tais padrões que de certa forma, morre, se tornando um anjo da morte. Analisando também as personagens femininas desenvolvidas por escritores vitorianos, como Dickens, Welsh (1999 apud GILBERT; GUBAR, 2000) afirma que o constante papel de salvação da morte desempenhado por elas se confunde, simbolicamente, com o próprio ato de morrer, e de dar a vida para salvar a vida de outrem. Essa representação se estendeu para outros campos da arte vitoriana, como pinturas, fotografias e o ideal de beleza feminino: mulheres pálidas, passivas, com pele de porcelana e a imobilidade dos mortos. A palidez era por vezes tão excessiva que a aparência de doença, juntamente ao uso de corpetes, o jejum e o hábito de beber vinagre, por vezes se concretizava enquanto fragilidade e fraqueza mórbidas. 
Dessa forma, a mulher vitoriana se tornou ainda mais próxima da morte. Não é por acaso, entretanto, que nos estudos psicanalíticos acerca do estranho, Freud (1919/2010) se debruce tão intensamente sobre a maior causa de estranhamento e angústia aos sujeitos: a morte. Símbolo supremo do estranho que é rechaçado e recalcado, o túmulo é um emblema sagrado no culto dos esquecidos (GILBERT; GUBAR, 2000). A mulher ocupava, e ainda ocupa, um espaço importante na esfera de grupos marginalizados. Ela não somente foi exorcizada da vida pública como também lhe foram negados os prazeres da vida sexual, se tornando uma espécie de fantasma não só da vida doméstica como de si mesma. Segundo Gilbert \& Gubar (2000), ela vivia uma existência póstuma, uma morte em vida.

Analisando as produções culturais dessa época, percebemos que para a imagem da mulher aprisionada existia um duplo com características diabólicas que refutava a ideologia hegemônica. De acordo com Gilbert e Gubar (2000), a literatura nos mostra que a Branca de Neve angelical era não somente assombrada, mas também caçada por sua Madrasta Má. Ou seja, para cada mulher submissa presa nas pequenezas da vida doméstica existia um negativo fotográfico que personificava seus desejos e angústias. Nos textos literários escritos por homens, era comum a exaltação das personagens angelicais e os castigos e punições aos seus duplos agressivos. Os duplos monstruosos não somente apareceram como um outro personagem separado do anjo, mas que também residem dentro dele. As figuras vilanizadas que pertencem ao final do espectro simbólico de representações femininas foram uma força coercitiva para as mulheres que desejavam expressar suas opiniões através da escrita. O que isso sugere é que o discurso de resistência feminino e a "presunção" de expô-lo, ou seja, a revolta em relação à dominação masculina, estão intrinsecamente ligadas.

A monstruosidade, figura presente em boa parte desses textos, pode ser pensada como o duplo de cada mulher escritora, que se depara com o monstro ou a louca que teme encontrar em si no lugar do anjo que deveria ser. Por vezes esses personagens surgem em sonhos, por terríveis experimentos, ou escondidos em cômodos sombrios, como se o próprio processo de escrever tivesse liberado uma mulher louca, agressiva e monstruosa, despertada de um silêncio que nem ela nem sua autora poderiam continuar a prolongar (GILBERT; GUBAR, 2000). Esses personagens com frequência aparecem como vilões ou contrastes à heroína ou herói principal da história, até serem punidos ou destruídos. Isso dramatiza a fragmentação da própria autora e sua contradição no sentido de aceitar ou rejeitar (ou, ao mesmo tempo aceitar $e$ rejeitar) a ideologia hegemônica.

Nesse sentido, compreendemos que, dados os impedimentos estruturais para a escrita da história feminina, ela acabou sendo construída, literariamente, de forma tangencial e 
escondida, perceptível pelo fato de que as mulheres autoras não se encaixam na história da literatura que é predominantemente masculina. A tese de Gilbert e Gubar (2000) é de que, por não terem um canône literário valorizado culturalmente, as escritoras deste período, que abriram as portas para as do presente e do futuro, sofreram uma crise em relação à autoria. $\mathrm{O}$ ato de ousar escrever as colocou em uma posição social de conflito direto com seus predecessores masculinos, fazendo com que o desejo e necessidade de escrever parecesse um capricho fútil. A batalha que travaram foi, não somente contra a estrutura social e a ideologia dominante, mas, também, contra as formas com as quais essa ideologia se envolve em sua percepção de si. As mulheres escritoras se afligem com a aceitação do público, com as vendas de seus livros, com seus conflitos artísticos internos, mas, principalmente, com as amarras ideológicas.

Entretanto, este movimento é ambíguo. A mulher escritora da era vitoriana era solitária, não gozando da oportunidade de discutir a solidão e seu desejo de escrever com muitas outras devido à grande quantidade de mulheres da época que aceitavam passivamente e reproduziam diariamente essa limitação de gênero. Como exposto por Eagleton (1997), a ideologia se mantém justamente por surgir dos próprios modos de produção e reprodução da vida, através das relações sociais, e, portanto, se estabelecer enquanto categoria fixa e inquestionável. Tanto os homens quanto as mulheres provavelmente tinham como imutável a ideia da inferioridade feminina, compreendendo que "sempre havia sido assim e sempre será", continuando a reprodução desta proposição ideológica.

Enquanto os escritores masculinos frequentemente revisavam a escola literária da época e renovavam sua maneira de escrever, as escritoras femininas estavam ainda em um período de pioneirismo literário que os homens tiveram, pela última vez, na Renascença. Cada mulher escritora ajudava na construção, por sua vez, de uma tradição de escrita totalmente nova. Se cada autora da contemporaneidade pode escrever com segurança e autoridade é porque suas antecessoras dos séculos XVIII e XIX o fizeram primeiro em um processo de isolamento, doença, alienação da sociedade e diagnósticos de loucura.

As mulheres que estavam entre as pioneiras a realizar uma incursão no mundo da escrita, nos séculos XVII, XVIII e até mesmo no século XIX, sofreram o primeiro choque do confronto com a ideologia hegemônica. Seus processos de escrita foram marcados pela sensação de inadequação, autocrítica e questionamentos acerca da validade de sua educação, já inferior, ressaltam Gilbert e Gubar (2000). Retomando os conceitos de ideologia de Marx e Engels (1845-1846/2007) e de Eagleton (1997), é comum que a ideologia seja sentida como uma potência incontrolável e incognoscível para os indivíduos, além de aparentemente 
independente da vontade e da ação dos homens.

A escrita de romances e histórias por mulheres também pode ser vista como um ato de resistência no âmbito da própria teoria literária. $\mathrm{O}$ romance se inaugurou enquanto gênero literário na Modernidade, e traçou um padrão masculino que foi de encontro à sociedade da época: um herói que passa por obstáculos sociais e econômicos até atingir uma posição mais alta na escala social. Essas histórias muitas vezes continham elementos de viagens a territórios longínquos e encontros com estrangeiros assustadores, até que o herói se firmasse como conquistador, também, de novos territórios (CLERY, 2002). A mulher escritora, ao se aventurar no romance, não expressava a trajetória de ascensão social feminina, já que ela ainda não existia. Portanto, apelou a recursos literários como metáforas e significados ocultos em camadas profundas de interpretação, contando suas histórias, sonhos, angústias e aspirações disfarçadamente.

O que ocorreu com diversos trabalhos de autoria feminina é que eles podiam ser apreciados pelo público geral que não capturava suas camadas de crítica e denúncia. Isso não quer dizer que a recepção do público destes textos foi fácil, rápida ou bem-sucedida, já que a escritora mulher era considerada uma excêntrica em meio à historiografia literária. Autoras como Jane Austen (com “A abadia de Northanger”, um escrito gótico que subverte o próprio gênero), Mary Shelley, as irmãs Brontë e Emily Dickinson, em seus diferentes contextos, produziram trabalhos literários que podem ser denominados de palimpsestos, ou seja, trabalhos em que suas camadas mais acessíveis escondem ou maquiam níveis de significado mais profundos e menos socialmente aceitáveis (GILBERT; GUBAR, 2000). Essas autoras conseguiram, de forma inovadora, alcançar alguma autoria e autoridade literária simultaneamente se conformando e subvertendo a ideologia hegemônica. O que as mulheres escritoras tanto escondiam em suas camadas de significados era, justamente, sua própria vida.

\section{FRANKENSTEIN, DE MARY SHELLEY: "FOI NUMA NOITE SOMBRIA DE NOVEMBRO..."}

A importância de retornar à Frankenstein é atribuída à sua posição axial no movimento de desenvolvimento pioneiro de escrita de autoria feminina, principalmente no campo do horror. É nos trabalhos iniciais que podemos perceber mais claramente as angústias da autoria feminina e seus elementos de resistência. Segundo Mellor (2003), Frankenstein é a análise literária mais penetrante na compreensão psicológica do homem "científico" moderno, dos perigos e desafios da pesquisa científica e das horríveis consequências, ainda que 
previsíveis, da exploração da natureza e de seus recursos assim como do esgarçamento de seus limites e do papel da mulher na sociedade de então.

A autora de Frankenstein, Mary Shelley, apesar de ter somente dezenove anos ao desenvolver sua monstruosa história, recebeu uma herança intelectual profícua. Sua mãe, Mary Wollstonecraft, foi a autora do famoso Vindication of the Rights of Women, de 1792, lido e relido por Mary Shelley ao longo de sua vida. Ela também teve acesso às duras críticas que a mãe recebeu, o que inseriu a jovem nas ideias propagadas pela ideologia hegemônica relativas ao papel da mulher (GILBERT; GUBAR, 2000). Após a morte da mãe, a casa de Mary e de suas irmãs virou um ponto de encontro de pensadores, médicos, cientistas, químicos e escritores, fertilizando a imaginação da jovem com as mais recentes descobertas científicas. Uma delas, em especial, se destaca no contexto deste trabalho: as tentativas de reanimação de cadáveres a partir de correntes de energia elétrica. Para além disso, o contato com o abjeto fora parte constituinte do crescimento de Mary, que morou ao lado de abatedouros e prisões em Londres (SEYMOUR, 2000).

Mais velha, Mary também teve contato com escritos de libertação feminina como também com as lutas da população negra e estrangeira. Seymour (2000) indica que Mary frequentemente se engajava em discussões do movimento contra a escravidão e se revoltava com a débil condição da Inglaterra pós-abolição. Segundo as pesquisas da biógrafa, a libertação dos negros escravizados no país não se deu na prática por atos ou leis, já que ficaram atados a uma situação de servidão doméstica, mas por seu próprio potencial revolucionário. A compreensão da criatura de Frankenstein como um ser não-humano e, portanto, não atrelado a noções de moralidade ou complexidade emocional foi uma construção cuidadosamente elaborada por Shelley (SEYMOUR, 2000). O fato de que muitas partes de cadáveres usados para sua criação são de pele amarelada ou escura e cabelos negros demonstra uma crítica de Mary às percepções vigentes de inferioridade desses grupos, assim como uma indicação de que eram esses os corpos que poderiam ser roubados sem comoção da população.

Considerando a ideia previamente introduzida de paternidade literária, a maternidade literária das escritoras mulheres se confunde com os próprios dilemas da maternidade, como Mary Shelley expressa por todo o mito de criação da criatura de Frankenstein. É comum que o horror e, principalmente o gótico, se misture à maternidade, já que diz respeito a uma abjeção, como pontua Kristeva (1982). Sua história pessoal ganha um tom ainda pior de sofrimento quando sabemos que Mary Shelley tinha consciência de que sua mãe havia morrido dando à luz a ela, o que marca sua percepção acerca da maternidade. Com insinuações de tentativas de 
suicídio e traições relativas à vida da mãe, Mary Shelley entrou em contato desde muito cedo com as opressões vividas pelas mulheres que também perpassariam sua vida por ser considerada uma mulher ousada. A criação de uma aberração monstruosa por Victor Frankenstein aponta para possíveis visões problemáticas de Mary a respeito de suas origens e de si mesma.

Entretanto, a análise da Criatura voltada às ansiedades pessoais de Mary acerca do papel de mãe é limitada. A obra, inserida na tradição literária romântica, expressa os temas principais deste movimento, como a preocupação com os supostos progressos científicos e tecnológicos prometidos pela Modernidade e a experiência humana, mas também, e talvez mais especialmente, a experiência de ser mulher na ideologia hegemônica da época. As críticas e resenhas tradicionais da obra tendem a voltar-se somente para as características míticas da narrativa, esquecendo-se ou ignorando os tons de crítica e angústia relativos às questões sociais. Mais do que o mito da criação, Frankenstein é uma representação do ato de escrever da mulher literata. Na introdução ao livro de 1831, Mary Shelley se refere à Frankenstein como sua hideous progeny, ou 'prole hedionda', sugerindo metaforicamente suas angústias em relação ao parto não somente desta história, mas de si mesma, e de tantas outras escritoras enquanto autoras. Portanto, a metáfora desenvolvida chega a um novo e mais amplo patamar de crítica social ao se referir à condição feminina como um todo e ao desenvolvimento da escrita por mulheres. Como Mellor (2003) aponta, a história de Frankenstein é "a história de escrever Frankenstein" (p. 11).

São algumas falas da criatura que demonstram sua similaridade intelectual à autora do romance. Um exemplo é o momento em que a criatura, já inserida no mundo da linguagem, cria uma lista de livros para se educar na cultura da época. Muitos dos livros que cita, como Paraíso Perdido, de Milton e Os sofrimentos do jovem Werther, de Goethe, são obras que, de acordo com os diários de Mary Shelley, fizeram parte de sua "educação literária" (GILBERT; GUBAR, 2000). Foram esses os livros que a iniciaram na literatura e, portanto, também no cânone masculino e na compreensão da ideologia hegemônica da escrita masculina. São as lições que toda autora (ou criatura monstruosa) deveria saber para estar a par da sociedade. Em dado momento, criatura e autora se confundem de tal forma que a personagem cita a educação doméstica e moral, de docilização e abnegação, compreendida com a leitura de Goethe, que se torna um livro de condutas para ser mulher/autora.

Ainda nesse sentido, a questão mais central da obra é, certamente, a descoberta de quem realmente é o monstro: o criador ou a criatura. Levados a crer pelo desenvolvimento narrativo que a criatura é monstruosa, muitos não observam o verdadeiro monstro, seu 
criador. A oficina de Victor Frankenstein é a geradora de questionamentos metafísicos e cósmicos acerca da paternidade/maternidade, da criação de seres através da ciência, da necessidade do homem de estar na posição de Deus/Pai e, nesse sentido, da criação textual pela mulher, ato bizarro e anormal no período em voga. Assim, a criação do monstro pelo cientista poderia ser percebida como a criação do próprio texto literário de autoria feminina, da mesma forma que a criatura em si também representa a busca da mulher escritora por sua história, por suas raízes, sendo ao mesmo tempo criadora e criatura. A descoberta das autoras mulheres - de serem desde o início, inadequadas, monstruosas e agressivas - ressoa na percepção da criatura de ser, ela mesma, advinda do nada, assim como as mulheres criaram uma tradição literária própria sem um legado que as amparasse e fornecesse caminhos.

É importante destacar que Frankenstein possui duas edições: a de 1818 e a de 1831 . A primeira, de 1818, foi editada por Percy Shelley, marido de Mary Shelley, na qual várias palavras, cenas e diálogos foram reescritos por ele para publicação. A edição de 1831 é a original, editada e publicada pela própria autora, de tom mais pessimista, crítico e negativo do que a primeira (MELLOR, 2003). As duas edições se distanciam também em estilos de escrita, já que o tom latinizado e erudito de Percy é confrontado pela escrita crua e coloquial de Mary. Apesar de aparentemente banal, essa diferença cabe como metáfora dos papeis aos quais cada edição se prestou: a pomposa de Percy, para agradar a uma elite intelectual e literária e que não gerasse grandes questionamentos, e a de Mary, determinada a impactar a sociedade com sua complexidade de ideias e não pela composição de frases. Enquanto Percy se esforçou para resignar o texto ao status quo, Mary tentou, com os recursos que tinha, expor um discurso dos excluídos.

A diferenciação mais perigosa, entretanto, é nas descrições da Criatura e em seu fim. A Criatura da edição de Percy é descrita, de acordo com Mellor (2003), como mais monstruosa e vil do que a de Mary, um ser demoníaco a ser destruído. Mary, entretanto, ignora a moral religiosa, tratando a Criatura como um alguém miserável, desprezado e subjugado. $\mathrm{O}$ ápice da distinção das versões se dá ao final do texto, em seu desfecho. Quando a Criatura salta da janela de um navio em direção às ondas do oceano, Percy a leva pela escuridão do mar e sela seu destino, perdendo-a para todo o sempre (MELLOR, 2003). Já Mary cria um final aberto, ao pontuar que o narrador perde a Criatura de vista, que se empurra pelas águas. A versão de Mary Shelley subentende uma atividade do monstro, e não a passividade de Percy, assim como uma possibilidade de salvação. Essas sutilezas são emblemáticas ao marcar a tentativa de retirar a potência do discurso de resistência construído pela autora. No texto alterado pelo marido, a criatura abjeta segue a linha de pensamento desejada pelas elites simbólicas, que a 
leva à sua destruição para manutenção da ordem social. Já Mary possibilita à sua Criatura o ato de resistir, de se salvar e de criar um novo lugar para si.

Assim como Mary Shelley, e todas as autoras mulheres, a história da criatura é definida por livros: todas elas, assim como a criatura, possuem um nascimento na escrita ahistórico. Também se assemelham, de forma mais óbvia, à deformidade, à falta de uma forma específica, à orfandade e, ainda mais caracteristicamente, à falta de um nome (GILBERT; GUBAR, 2000). A percepção de Mary Shelley acerca da autoria feminina ecoa mais fortemente quando a criatura, após observar uma família "normal", se vê refletida no espelho d'água de um lago. Apesar de uma possível referência ao mito de Narciso, a criatura não se apaixona pelo reflexo, mas fica mortificada ao perceber que a imagem horrível era, de fato, ela mesma. Essa passagem parece representar a visão contraditória de si da mulher escritora já descrita anteriormente, presa entre as possibilidades de construção da autoria e a crucificação e repúdio pela sociedade. Além disso, a Criatura, após ser rejeitada pela família burguesa "normal" que constantemente observa e ajuda, se revolta contra ela. A narrativa, então, reitera a perspectiva de Mary acerca da hipocrisia de seu tempo, um aviso do que pode ocorrer quando um grupo oprimido toma consciência de sua condição.

O próprio local ocupado pela monstruosidade é classificado como sombrio, e sua ilegitimidade parece encarnar esse ambiente inominável. Sabemos que, psicanaliticamente, o local inominável é, muitas vezes, o não-lugar do abjeto, do que é expulso dramaticamente para fora do corpo (KRISTEVA, 1928). Local inominável é, também, o local social da própria Mary Shelley na sociedade da época, que, para além do grande fardo de ser uma mulher presunçosa que ousava escrever, ainda carregava o peso da morte de filhos e familiares, de ter vivido com seu marido antes do casamento e de ter opiniões contraditórias às propagadas na época.

Abjeto, no geral, de acordo com Kristeva (1982), é o que desarmoniza o sistema de regras sob o qual a sociedade opera, seja a cultura, as leis, a religião ou os padrões de moralidade. Nesse sentido, em Frankenstein o binômio Victor Frankenstein/Criatura expõe o abjeto, sendo a Criatura um exemplo de monstruosidade criada apenas para ser destruída. Apesar de ser uma forma de manter o status quo, destruindo o que foge às normas sociais, o próprio ato de gerar a monstruosidade e apresentar o personagem ao público já faz dele inesquecível, dando-lhe corpo e subsequentemente voz. Abjetar algo tem a consequência inevitável de fazê-lo visível a quem antes não o via, de acordo com Kristeva (1982). Esse talvez tenha sido um dos grandes trunfos da literatura gótica e de horror. Ainda que em Frankenstein o corpo abjeto se apresente literalmente enquanto Criatura, podemos pensar que 
os discursos de resistência que desestabilizam e subvertem a ideologia hegemônica se constituem também como abjetos. Isso coloca, pois, em xeque as frágeis verdades que constituem as proposições ideológicas, que definem o lugar e o não-lugar dos grupos marginalizados.

$\mathrm{Na}$ literatura gótica de autoria feminina, no geral, são comuns também as temáticas de aprisionamento e posterior libertação. Não por acaso, os ambientes são casas ou porões, que apresentam elementos como fantasias, espelhos, vestidos e roupas, estátuas e pinturas, armários ou baús e toda a parafernália doméstica que assombra a vida da mulher desses séculos. É pela violência do duplo que a mulher escapa tanto da casa quanto de seu domínio doméstico imposto pelo homem, portanto. Os temas do gótico são predominantemente os temas da vida feminina. Podemos citar personagens como Bertha Mason, "a louca do sótão", construída por Charlotte Brontë em Jane Eyre que pode ser compreendida como o duplo feminino da protagonista e que toca na questão da conexão histórica do feminino com a loucura; Catherine Earnshaw, de O morro dos ventos uivantes escrito por Emily Brontë, de espírito "selvagem" que definha aos olhos do leitor após seu casamento e retorna de forma fantasmática; a narradora sem nome (que pode ou não se chamar Jane) de O papel de parede amarelo de Charlotte Perkins e seu duplo preso no papel de parede do quarto da mansão ancestral em que foi confinada por seu marido.

Isso não quer dizer que autores masculinos não tenham utilizado temas similares ou se interessado pelo gótico. Grandes nomes da literatura como Dickens e Poe, de acordo com Gilbert e Gubar (2000), fizeram uso de prisões, celas, tumbas e sótãos. Foram responsáveis, também, por criar elementos que servem de base para o horror contemporâneo. Entretanto, eles puderam representar tais imagens de forma objetiva e exploratória, vagando tranquilamente por entre as vicissitudes de sua psiquê, enquanto as autoras viveram tais confinamentos nos âmbitos social e material.

Outra maneira metafórica de representar a imagem feminina hegemônica foi a construção de personagens acometidas por algum tipo de incapacidade intelectual, que ao mesmo tempo demonstram a inferiorização intelectual requerida das mulheres (em especial em relação às escritoras) e a paródia (GILBERT; GUBAR, 2000). Em Frankenstein, o monstro não nasce inserido na linguagem, mas a aprende, demonstrando a alienação das mulheres do mundo da escrita, da linguagem e, portanto, da construção de sua própria narrativa. Para além de somente terem que aprender como se expressar no mundo das palavras, por vezes essa inescapável ignorância remete a algo que foi esquecido ou recalcado. Os aspectos recalcados são justamente os que são barrados pela ideologia hegemônica: 
a herança feminina nas letras e tantas histórias de mulheres que poderiam ter sido contadas ou que foram suprimidas pelas linhas da historiografia. Trazer esse recalcado à luz construindo narrativas e discursos de resistência abre possibilidades de criação de novos lugares e ideais discursivos, simbólicos e sociais para as mulheres. Ao gerar sua Criatura, Shelley a costura a partir de cadáveres socialmente sem valor, sem uma história ou herança própria, ainda que feita de tantos corpos com histórias. Tais corpos, unidos em uma criatura, têm suas conquistas, angústias e sentimentos representados, agora juntos. Shelley os permite andar e falar, e, como pontua Bosi (2002), observar os nós da cultura por outra perspectiva, desvelando as proposições ideológicas. Tirá-los de onde foram enterrados ou desovados e dar-lhes um corpo, uma capacidade de conhecer e de se inserir na linguagem é ressuscitá-los no campo da cultura e do simbólico, e, em última instância, é resistir. A luta da Criatura por seu lugar na sociedade engloba a luta de vários grupos, ainda que o escopo deste trabalho seja o do feminino. Foi pelas mãos de Frankenstein, criador e criatura, que Mary Shelley escreveu a sua história e de tantas outras.

\section{REFERÊNCIAS BIBLIOGRÁFICAS}

ANJOS, J. C. G. dos. BOURDIEU, Pierre. As regras da arte: gênese e estrutura do campo literário. São Paulo: Companhia das Letras, 1996. 432p. Horizontes antropológicos, v. 4, n. 9, p. 325-327, 1998.

AUSTEN, J. Persuasion. London: Collector's Library, 2004. (Obra original publicada em 1818).

AUERBACH, E. Mimesis: a representação da realidade na literatura ocidental. 6. ed. São Paulo: Perspectiva, 2013. (Obra original publicada em 1946).

BEAUVOIR, S. de. O Segundo Sexo. Tradução de Sérgio Milliet. São Paulo: Nova Fronteira, 2010. (Obra original publicada em 1949).

BOSI, A. Narrativa e resistência. Itinerários, v. 10, p.11-27, 1996.

BOURDIEU, P. As regras da arte: gênese e estrutura do campo literário. Tradução de Maria Lucia Machado. São Paulo: Companhia das Letras, 1996.

Os usos sociais da ciência: por uma sociologia clínica do campo científico. São Paulo: UNESP, 2004.

CLERY, E-J. The genesis of gothic fiction. In: HOGLE, J. The Cambridge Companion to Gothic Fiction. New York: Cambridge University Press, 2002, p. 21-40.

EAGLETON, T. Ideologia: uma introdução. Tradução de Luís Carlos Borges e Silvana 
Vieira. São Paulo: Editora Boitempo, 1997. (Obra original publicada em 1991).

FEDERICI, S. Calibã e a bruxa: mulheres, corpo e acumulação primitiva. Tradução de Coletivo Sycorax. $1^{\mathrm{a}}$ ed. São Paulo: Elefante, 2017.

FITZGERALD, L. Female Gothic and the Institucionalization of Gothic Studies. In: WALlACE, D.; SMITH, A. The Female Gothic: New Directions. London: Palgrave Macmillan, 2009, p. 13-24.

FREUD, S. O inquietante. In: Obras Completas. Tradução de Paulo César de Souza. São Paulo: Companhia das Letras, 2010, p. 161-238. v. 14. (Obra original publicada em 1919).

KRISTEVA, J. Powers of horror: an essay on abjection. New York: Columbia University Press, 1982.

LIMA, S. C. de; COROA, M. L. M. S.; LIMA, P. M. R. de. Identidade de velhos: modos de identificação e discursos de resistência na velhice. Domínios De Lingu@gem, v. 10, n. 3, p. 903-926, 2016.

LÖWY, M.; SAYRE, R. Revolta e melancolia. Tradução de Nair Fonseca. São Paulo: Boitempo, 2015.

MARX, K.; ENGELS, F. A ideologia alemã. Tradução de Rubens Enderle, Nélio Schneider e Luciano Cavini Martorano. São Paulo: Boitempo, 2007. (Obra original publicada em 18451846).

MASSÉ, M. Psychoanalysis and the Gothic. In: PUNTER, D. (Ed.) A new companion to the gothic. Chichester: Blackwell Publishing, 2012, p. 307-320.

MELLOR, A. K. Making a monster: an introduction to Frankenstein. In: SCHOR, E. (Ed.) The Cambridge Companion to Mary Shelley. New York: Cambridge University Press, 2003, p. 9-25.

REIS, M. A normatização dos corpos e a regulação dos gêneros no processo de transição do feudalismo para o capitalismo. Topoi, v. 19, n. 39, p.150-156, 2018.

ROSSI, A. D.; ZANINI, C., BARROS, F. M. de; FRANÇA, J. (2018). Estudos do Gótico. Recuperado de: http://www.abralic.org.br/publicacoes/ebooks/.

SHELlEY, M. Frankenstein, or, The Modern Prometheus. Revised Edition. London: Penguin Classics, 2003. (Obra original publicada em 1818).

Frankenstein ou O Prometeu moderno. Tradução de Christian Schwartz. São Paulo: Penguin Companhia, 2015. (Obra original publicada em 1831).

TEIXEIRA, N. C. R. B. Entre o ser e o estar: o feminino no discurso literário. Guairacá, v. 25, n.1, p. 81-102, 2009.

VASCONCELOS, S. G. T. A formação do romance inglês. São Paulo: Editora Hucitec, 2007. 
WALLACE, D. "The Haunting Idea": female gothic metaphors and feminist theory. In: .; SMITH, A. The Female Gothic: New Directions. London: Palgrave Macmillan, 2009, p. 26-41.

.; SMITH, A. Female Gothic: then and now. Gothic Studies, v. 6, n.1, p.1-7, 2004.

. Introduction: defining the female gothic. In: WALLACE, D.; SMITH, A. The Female Gothic: New Directions. London: Palgrave Macmillan, 2009, p. 1-12.

WOOLF, V. A room of one's own. London: Penguin Books, 2019. (Obra original publicada em 1928).

Mulheres e ficção. In: Mulheres e ficção. Tradução de Leonardo Froés. São Paulo: Penguin \& Companhia das Letras. (Obra original publicada em 1929).

- Profissões para mulheres e outros artigos feministas. Tradução de Denise Bottmann. $1^{\text {a }}$ ed. Porto Alegre: L\&PM, 2012. (Obra original publicada em 1942).

Recebido: $30 / 04 / 2020$

Aprovado: 08/06/2020 